\title{
ASIA'S BOARD DIVERSITY: DOES DIRECTOR DIVERSITY ON BOARD AFFECT FIRM PERFORMANCE?
}

\author{
Novitasari Devi \\ Economic and Business Faculty, University of Airlangga, Surabaya, Indonesia \\ E-mail: devi.novitasari-2016@feb.unair.ac.id
}

\begin{abstract}
Some countries in Europe have passed laws that require every company to have a woman on the company's board of directors. Asia still does not have legislation as in some countries in Europe, so women's board office companies in Asia are small or nonexistent. In this study, board diversity was measured by 4 variables; these are gender diversity, age of director, director's educational background, and outside director, with board size and firm size as control variables, while firm performance is measured by using return on asset. The population in this study was companies included in Forbes Asia's 50 Best Big Public Companies of 2014-2016. The results show that board diversity does not affect the performance of the company.
\end{abstract}

\section{KEY WORDS}

Board diversity, director of diversity, corporate governance, firm performance.

The role of a woman becomes more common in the work environment, they play an important role in leadership positions throughout the company. More companies began training in introducing programs and workshops to promote gender diversity and equity. In 2005 , Norway became the first country to introduce the rules of women's quota on the board of directors by passing a law requiring companies to have at least $40 \%$ of women on its board of directors in 2008. In 2007, Spain passed a guideline encouraging the company to increase its share women in the company's board of $40 \%$ by 2015 . In January 2011 , French law was modified and quotas were introduced to increase women's representation on the board of directors by $20 \%$ by 2014 and $40 \%$ by 2017 , for both listed and unlisted companies. Similarly, other countries such as Belgium, Italy and the Netherlands are awaiting the enactment of the same law. Meanwhile some countries such as Australia, Germany and UK encourage companies to voluntarily set the quota. (Deloitte, 2011)

In Asia, only a few of women are on the board of directors of companies and almost half of companies in Asia do not have a female board of directors. Recorded only $8.6 \%$ female board of directors at companies in Hong Kong, 8.1\% in China and Malaysia reached $7.8 \%$. Smaller figures were obtained for companies in Singapore that is only $6.4 \%$ and $4.7 \%$ in India. More than $70 \%$ of the board of directors in six Asian countries - China, Hong Kong, India, Malaysia, New Zealand and Singapore - does not have an independent female board of directors. Similarly, very rarely found 3 (three) or more women on board of directors of one company and hardly found 3 (three) or more women who become independent board of directors in one company. (Yi, 2011). Carter et al. (2003) found that firms with two or more women in board members had firm value (which was proportional to Tobin's $Q$ ratio) higher than firms with fewer women in board members of less than two people.

Campbell \& Minguez-Vera (2008) who argue that greater gender diversity among council members results in more diverse opinions and diverse critical thinking making decision making more time consuming and less effective. The composition of board members is an issue related to corporate governance. The existence of distribution or diversity on board members is believed to affect the value of the company, both in the short term and long term. Council diversity is often called to increase board effectiveness and monitoring, and will improve company performance (Blake, 1991) in Carter et al (2003). This diversity encompasses the diversity of gender, age, ethnicity, educational background and professional experience of board members. Board diversity is expected to have a positive 
impact. The greater the dispersion within council members can lead to more conflict, but the dispersion can provide an alternative solution to an increasingly diverse problem than homogeneous board members.

Our study is unique in that we consider the outside director, age, educational background and gender diversity in this analysis that are not common in the literature. This research also use control variable that is board size and company size. We believe that gender diversity, the age of the board of directors, the educational background of the board of directors and the outside director is not the same phenomenon and will not affect the company in the same way. This study aims to examine the effects of gender diversity, the age of the board of directors, the educational background of the board of directors and the outside director on the performance of a company as measured by ROA.

\section{LITERATURE REVIEW AND HYPOTHESIS DEVELOPMENT}

Corporate Governance. According to Turnbull (Syakhroza 2003) corporate governance is a series of systems organized by considering factors affecting institutional processes (including factors related to corporate governance regulators). The company is called in good condition if the company meets the principles such as fairness, transparency, accountability, and responsibility. In research conducted by Surya and Yustiavandana (2006), revealed that good application of basic principles of good corporate governance (GCG) can increase company value.

In this study, it is seen not only the gender diversity, but also from the age of the board of directors, educational background, and also outside director in the company. This study further examines the diversity that exists on the board of directors in the company. The existence of distribution or diversity on board members is believed to affect the performance of the company, both in the short and long term. Based on this, this study will examine the characteristic factors of gender, age of the Board of Directors, educational background and outside directors in Asia.

The Role of Woman on Board. Board diversity becomes an interesting thing to look at in relation to corporate governance because there is still the assumption that men are more fit to occupy important positions in the company. Recorded only $8.6 \%$ female board of directors at companies in Hong Kong, $8.1 \%$ in China and Malaysia reached $7.8 \%$. Smaller figures were obtained for companies in Singapore that is only $6.4 \%$ and $4.7 \%$ in India. More than $70 \%$ of the board of directors in six Asian countries - China, Hong Kong, India, Malaysia, New Zealand and Singapore - does not have an independent female board of directors. (Yi, 2011).

Khrisnan and Parsons (2008) found that gender diversity in top management can improve the company's financial performance. McKinsey (2007) found that firms where strong women's presence within the Board of Directors have better governance and financial performance. While research results Carter et al. (2003) found that firms with two or more women in board members had firm value (which was proportional to Tobin's $Q$ ratio) higher than firms with fewer women in board members of less than two people. From the description above research hypothesis as follows:

$\mathrm{H} 1$ : The role of women on board members has an effect on the firm performance.

The Proportion of Outside Director. Inside the board diversity contained the board composition which draws the outside director's nprosentase inside the board (Ohlson in Faizal 2004). A board with a strongly independent composition of outside directors will have more stringent managerial control behavior than a management-controlled board. The ability of independent directors to influence management decisions will increase with the proportion of their board standing. Hermalin and Weisbach (2000 in Carter et al., 2003) have found strong and significant external directors influence on performance. Limpaphayon and Sukcharoensin (n.d) through their research in Thailand found that the board of directors dominated by outside directors with low managerialownership has a strong and significant influence on the company's performance. Based on the description, can be formulated hypothesis as follows:

$\mathrm{H} 2$ : The proportion of outside director on board has an effect on the firm performance. 
The Age of Director on Board. According to Hurlock (1999), one's adulthood can be divided into three stages, namely early adulthood (early adulthood) starting from the age of 18-40 years, middle age (middle adult) beginning at age 40-60 years, and adult (late adult) that begins at age 60 to death. At the age of 40 years, someone will reach his career. Adulthood is a period of decline in physical skills and the greater the responsibility, other than that this period is a time when people achieve and maintain satisfaction in his career (Santrock 1995). Levinson and Peskin (1981) as quoted by Santrock (1995) who stated that the age of 34-50 years is the healthiest, quietest, most self-controlled, and most responsible group. At the age of 40-45 years, a person has climbed the career path as far as they can and has reached a stable place in his career at the age of 40 years. The statement is like the proverb "life begins at 40".

In late adulthood, a person's speed to process information decreases, and is less able to retrieve information that has been stored in his memory. This is what causes when a person enters adulthood advanced, they prepare for retirement. According to Brandstadter and Renner (in Santrock 1995) one thing to consider in terms of advanced adulthood is increased wisdom as one gets older.

Supported by Dagsson \& Larsson (2011) research in modern times as it is today a growing and emerging generation of young people with computers and the internet, the younger generation of board members allows more information and better experience in the company's business. And many assumptions at a young age a person is more open to something new.

This shows that age can affect a person's performance in a company that can then affect the company's performance. In addition, older workers typically show more loyalty to the company than younger workers (Dessler 1997). But in this study we use the age above 50 years because according to us at that age a director is wiser and trusted in making decisions. From the above description can be formulated hypothesis as follows:

H3: The age of director on board has an effect to firm performance.

The Director Educational Background. Kusumastuti (2007) states that the educational backgrounds of the members of the council have an effect on the knowledge they have. By having existing business and economic knowledge, at least board members have better ability to manage a business and make business decisions than not having business and economic knowledge. Ultimately this will affect the value of the company. The title or background of education in the financial field of board members will also automatically provide many benefits for the financial management of the company (Jeanjean and Stolowy, 2009).

Bray and Howard and Golan as quoted by Santrock (1995) state that university education helps someone in his career progress, where a highly educated person will have a higher and faster career path. Nurudin (2004) mentions that research from Harvard University in the United States revealed that success is not solely determined by the knowledge and technical skills (hard skills), but by self-managing skills and other people (soft skill). This study revealed, success is only determined about $20 \%$ with hard skills and the remaining $80 \%$ with soft skills. Understanding of the term hardskill is a skill that can produce something of its nature visible and immediate. Unlike hardskill, soft skills are invisible and not immediate. Soft skills include interaction with the lives of others. From the description above it can be made as follows hypothesis:

$\mathrm{H} 4$ : The director educational background on board has an effect to firm performance.

\section{METHODS OF RESEARCH}

The sample of this study is a publicly listed company in Forbes Asia's 50 Best Big Public Companies. Samples are taken based on purposive sampling method with criteria: (1) Companies included in Forbes Asia's 50 Best Big Public Companies 2014-2016; (2) Other non-financial services and non-service companies; and (3) the company must have a financial statement containing a statement of financial position and annual report; 
(4) Companies that have data required for this research. Based on the criteria, 86 companies were sampled as described in the table below.

Table 1 - Research Sample

\begin{tabular}{|c|l|c|}
\hline \multicolumn{1}{|c|}{ Criteria are used } & Total Companies \\
\hline 1. & Company which listed in Forbes & 150 \\
\hline 2. & $\begin{array}{l}\text { Asia's 50 Best Big Public Companies 2014-2016 } \\
\text { Bank and other service company }\end{array}$ & $(50)$ \\
\hline 3. & Companies that don't have any data which needed for the research & $(14)$ \\
\hline \multicolumn{2}{|c|}{ Total samples are used } & 86 \\
\hline
\end{tabular}

The data used a secondary data derived from annual reports of each company obtained from each company's website listed in Forbes Asia's 50 best big public companies 20142015. Dependent variable used in this research is firm performance (firm performance). Company performance is calculated based on information based on price to book value. In addition to measuring company performance based on financial accounting information, then this measurement also uses Return On Assets (ROA).

The independent variable in this research is the board diversity. In this study, the board diversity includes the age distribution, gender diversity of the board of directors, the educational background, and the proportion of outsiders in the board. For the measurement of each independent variable: a) Gender (GEN), measured by a dummy variable, where 0 states no female directors in the board and 1 stating there are female directors in the board, b) Proportion of outside directors (OUTSIDER) measured using the percentage of outsider directors in board members, c) Age (AGE), measured using board council proposals over 50 years and d) Educational background (EDU), measured using the proportion of board members with educational background in economics, business and finance.

The control variables used in this study as used in the study of Carter et al. (2003), namely: a) Board size (BSIZE), measured by the number of board members and b) Firm size (FSIZE), measured by the natural logarithm of the total assets of the firm.

Data Analysis Technique. In this research, the analytical technique used is multiple linear regression analysis. Multiple linear regression analysis was used to determine the effect of gender diversity, age of the Board of Directors, educational background, and outside director (independent variable) on Company Performance (dependent variable). The statistical calculation in this study uses SPSS (Statistics Packages for Social Science) version 22 program. The regression model used is bellow:

$$
\text { PERFORMANCE }=\beta_{0}+\beta_{1} \text { GEN }+\beta_{2} \text { AGE }+\beta_{3} \text { EDU }+\beta_{4} \text { OUT }+\beta_{5} \text { SIZE }+e
$$

Where:

$$
\begin{aligned}
& \text { PERFORMANCE = Firm Performance; } \\
& \beta_{0}=\text { Constanta; } \\
& \beta_{1} \text { GEN = Gender Diversity; } \\
& \beta_{2} \text { AGE = The Age of Director; } \\
& \beta_{3} \text { EDU = Educational Background; } \\
& \beta_{4} \text { OUT = Outside Director; } \\
& \beta_{5} \text { SIZE = Control Varable for firm performance; } \\
& \text { e = Error. }
\end{aligned}
$$

\section{RESULTS AND DISCUSSION}

The average ROA is worth $15.9136 \%$ which means the average sample company has Return on Asset with the value. Of the total sample companies, there are 27 companies that have below average ROA and 59 companies have ROA values above average. This means that $31.39 \%$ of the sample companies have an ROA value that is smaller than the average. 
For the aged (AGE) variable, an average of $59.23 \%$ indicates that most of the sample companies are board members over the age of 50 years. All of the companies in this study sample had board members over the age of 50 years. This suggests that decision making in the sample company is dominated by the elderly, in which the elderly remain in a respected position (Kuntjoro 2002).

The result from the educational background of economics, business, and finance (EDU), there are $60.76 \%$ board members in sample companies with educational background in economics, business and finance. But there is one sample company whose membership of the board has absolutely no educational background in economics, business and finance. The average value indicates that board members with economic and business education and financial backgrounds are important in the company.

The following is a general description of the research data used in this study:

Table 2 - Summary of Statistic Description

\begin{tabular}{|c|c|c|}
\hline Variable & Mean & Std. Deviation \\
\hline ROA & 15.9136 & 12.06566 \\
\hline AGE & 0.5923 & 0.23340 \\
\hline EDU & 0.6076 & 0.21632 \\
\hline OUTSIDER & 0.3947 & 0.19594 \\
\hline BSIZE & 8.71 & 3.115 \\
\hline FSIZE & 11.8436 & 0.65556 \\
\hline
\end{tabular}

For the proportion of outsider director (OUTSIDER), there are 7 sample companies that do not have board members who are outsider directors. When viewed from the average value, it can be said that the proportion of outsider directors in the sample company is enough that only amounted to $39.47 \%$. This is more than enough because based on research conducted by Surya and Yustiavandana (2006), based on recommendation Code for Good Corporate Governance recommends that at least $20 \%$ of the members of the board of commissioners and board of directors are independent members.

For board size (BSIZE), the average sample company has a board of 8-9 people. But there are also some companies have the largest number of board members among the sample companies, ie as many as 20 people. In firm size variables (FSIZE), the average sample company has firm size that is not much different, it is seen from the standard deviation of 0.66 .

The high number of women in Asia working in leadership positions is also seen from the table above which describes descriptive statistics for women's presence on the board of directors. Of the 86 sample companies, 23 companies or $26.7 \%$ did not have female council members, while $73.3 \%$ of the sample companies had female councilor.

The table below summarizes the tests conducted on the six previously mentioned hypotheses:

Table 3 - Summary of Regression Results

\begin{tabular}{|c|c|c|}
\hline Variable & Coefficient & $t$-value \\
\hline (Constant) & 21,908 & 3,359 \\
\hline GENDER & 0.763 & 0.363 \\
\hline AGE & -7.529 & -2.305 \\
\hline EDU & -1.875 & -0.304 \\
\hline OUTSIDER & 2.555 & 1.371 \\
\hline BSIZE & -0.512 & -0.491 \\
\hline FSIZE & -0.339 & -1.840 \\
\hline
\end{tabular}

$R 2=0.30 ;$ Adjusted $R 2=0.18 ; F=0,626 ; \operatorname{Sig} .(F)=0.645$

In order to obtain a good regression model, the data must pass the classical assumption test that includes normality, multicolinearity, heterocentricity, and autocorrelation (Ghozali 2005). Multi-collinearity test results showed free data from multicolinearity symptom, where all independent variables used in this study had tolerance value $>0.10$ or VIF $<10$. 
Normality test results with One Sample Kolmogorov Smirnov Test that the assumption of normality is met, in which the significance obtained for distri- bution of annoying or residual variables is more than 0.05 . Similarly, heteroscedasticity test results with scatterplot graphs, it is seen that the points spread either above or below the value 0 on the horizontal axis, so there is no problem of heterokedastisitas. The output of this classic assumption test can be seen in the appendix. Therefore it can be concluded that the regression model used in this study passed the classical assumption test.

Based on table 3, it can be seen that simultaneously, the independent variables used in this research are women in board, age of board of director, economic and business education background, proportion of outside directors, This is seen from the significance level of $F$ test of more than $10 \%$. The results of this study differ from those of Cox and Blake (1991) and Robinson and Dechant (1997) in Carter et al. (2003) that the distribution in the board of diversity is believed to have an effect on the value of the company.

Variations of the variables used in the research model can provide an explanation of the dependent variable variation of $18 \%$ (adjusted R2), while the remaining $82 \%$ is explained by other variables outside the model. The findings are in line with the opinions of Hermalin and Weisbach (2000) as quoted by Carter et al. (2003) which provides an important point, in which agency theory simply can not provide a clear predictor of the relationship between board diversity and firm value.

Based on the table, partially found those variables also have no effect on firm performance. This may be because women are less of a risk than men, so women have a lower percentage in some positions than men (Charness and Gneezy 2004). So women have no influence on firm performance.

The proportion of outside directors (OUTSIDER) variables found statistically did not affect firm values. According to Surya and Yustiavandana (2006), based on recommendation Code for Good Corporate Governance recommends that at least $20 \%$ of the members of the board of commissioners and board of directors are independent members. Although from the descriptive statistics it can be seen that the average outside directors in the sample company is more than $20 \%$ but this outsider variable has no effect on the performance of the company which may be caused because the companies already have members of the board of directors who are very competent in their field.

The age variable of board members (AGE) was also found not to affect firm value. Relating to the lack of an age-related influence on the value of a company is supposedly an older person, more and more health problems are faced, which in turn will lead to a decrease in intellectual ability (Siegler \& Costa in Prasetyaningrum 2005).

The proportion of board members with business and economic background (BSTUDY) was found to have no effect on company performance as measured by ROA ratio. The absence of such influence is due to the fact that in this study only defines the educational background specifically for economy and business and finance. There is a possibility that the board members' educational background in accordance with the type of business enterprise that can support the continuity of the company's business is more necessary. So in this case board members who have an educational background termed "discipline" is necessary in running the company's business

Board size variables (BSIZE) and firm size as control variables were found to have no effect on firm value. The results of the study discussing the size of the board of directors and the size of the company is still not consistent. According to Pfefer (1973) and Pearce and Zahra (1992), increasing the size and diversity of the board of directors will benefit the company, but Yermack (1996) and Eisenbarg et al. (1998), as quoted by Faizal (2004) in his research found that the number of small directors will improve the performance of the company.

The results of this study are match with Darmawati et al. (2004) which states that the effect of firm size on corporate governance is still unclear. Large companies can have greater agency problems that require better corporate governance (Durnev and Kim as quoted by Darmawati et al., 2006). On the other hand, Klapper and Love (Darmawati et al., 2006) 
suggest that small firms can have growth opportunities requiring external funds that then impact on the need for better corporate governance mechanisms.

\section{CONCLUSION}

The findings of the research and analysis described above, it can be concluded that the distribution of board members (board diversity) does not affect the performance of companies as measured by ROA. The existence of women in the board (Gender diversity), the proportion of outside directors, the age of board members, and the proportion of board members with economic, business and financial education backgrounds have been found to have an effect on the company's performance.

Future research is expected to be done more specifically and more deeply to better explain the dependent variable (firm performance measured by ROA), can also include other additional variables such as ownership structure, annual meeting, and debt ratio so that the results obtained can be better.

\section{REFERENCES}

1. Brammer, S., Millington, A., \& Pavelin, S. 2007. Gender and ethnic diversity among UK corporate boards. Corporate Governance:An International Review, 15: 393-403.

2. Campbell, K. \& Minguez-Vera, A., 2008. Gender Diversity in the Boardroom and Firm Financial Performance. Journal of Business Ethics, 83, pp. 435-451.

3. Carter, D.A., Simkins, B.J.,Simpson., W.G. 2003, Corporate Governance, Board Diversity, and Firm Value, The Financial Review, Vol. 38 (1), p. 33-53

4. Crawford, M. 2006, Transformation: Women, Gender, and Psychology, Mc Graw Hill, NY.

5. Dagsson, S., 2011. How age diversity on the Board of Directors affects Firm Performance. Thesis. Business Administratin Blekinge Institute of Technology.

6. Deloitte. 2011. Women in the Boardroom: A Global Perspective. UK: Deloitte Global.

7. Dessler, G. 1997, Human Resources Manag. Edisi 7 Jilid 1 terjemahan, PT. Prenhallindo.

8. Elsaid, Eahab. 2014. Examining the Effect Of Change In DEWAN DIREKSI Gender, Functional And Educational Background On Firm Performance And Risk, The Journal Of Applied Business Research - November/ Desember. Volume 30 Number 6.

9. Faizal. 2004, "Analisis Agency Cost, Struktur Kepemilikan dan Mekanisme Corporate Governance", Simposium Nasonal Akuntansi VII Denpasar Bali

10. Hillman, A. J., Cannella, A. A., Jr., \& Harris, I. C. 2002.Women and racial minorities in the boardroom: How do directors differ? Journal of Management, 28: 747-763.

11. Hurlock, Elizabeth B. 1999, Psikologi Perkembangan: Suatu Pendekatan Sepanjang RentangKehidupan, Penerbit Erlangga, Jakarta

12. Jeanjean, T., 2009. Determinants of board members' financial expertise - empirical evidence from France. The International Journal of Accounting, Vol. 44 (4), p. 378-402.

13. Krishnan, G.P. and Parsons, L.M. 2008, Going to the bottom line: an exploration of gender and earnings quality. Journal of Business Ethics, vol. 78 (1-2), p. 65-76.

14. Kusumastuti, S., 2007. Pengaruh Board Diversity Terhadap Nilai Perusahaan Dalam Perspektif Corporate Governance. Jurnal Akuntansi dan Keuangan, vol. 9 (2), p.88-98.

15. Nurudin. 2004, "Menggugat Pendidikan Hard Skil", http://www.suaramerdeka.com

16. Peterson, C. A. \& Philpot, J. 2007. Women's roles on U. S. Fortune 500 boards: Director expertise and committee memberships. Journal of Business Ethics, 72: 177-196.

17. Peterson, C. A., Philpot, J., \& O'Shaughnessy, K. C. 2007. African-American diversity in the boardrooms of the US Fortune 500: Director presence, expertise and committee membership. Corporate Governance: An International Review, 15: 558-575.

18. Santrock, John W. 1995, Life Span Development: Perkembangan Masa Hidup, edisi 5 jilid II,Penerbit Erlangga, Jakarta

19. Syakhroza, A. 2003, "Teori Corporate Governance“, Usahawan, No. 08 Tahun XXXII.

20. Yi A. 2011. Mind the Gap: Half of Asia's boards have no women, a risky position for governance and growth. Singapore: Korn/Ferry Institute. 